\title{
Benefits of Yankari Game Reserve to its Host Communities
}

\author{
Okochi, A.E. ${ }^{1}$; Tee T.N. ${ }^{2}$ and Egwumah, P.O. ${ }^{3}$ \\ ${ }^{1,2}$ Department of Social and Environmental Forestry, College of Forestry and Fisheries, University of \\ Agriculture, Makurdi Nigeria \\ ${ }^{3}$ Department of Wildlife and Range Management, College of Forestry and Fisheries, University of Agriculture, \\ Makurdi Nigeria
}

\begin{abstract}
This study determines the benefits of Yankari Game Reserve (YGR) to its host communities. Applying a systematic random sampling approach, 320 respondents were identified around the host communities and administered with semi-structured questionnaire to elicit data that were analyzed using descriptive statistics. Male and female respondents were $76.3 \%$ and $23.7 \%$ respectively indicating male dominance over female. The greater proportion (63.1\%) of the respondents had no western education, while $36.9 \%$ had. A higher proportion (81.6\%) of the respondents was married while $18.4 \%$ was single. By aggregate $51.2 \%$ of the respondents comprised 10 household members and above, while $48.8 \%$ were below 10 members. The benefits of YGR to host communities were collection of eight categories of non-timber forest products with fuel-wood (56.3\%) and bushmeat (16.9\%) dominating. Other benefits were power supply (40.6\%), health facilities (21.8\%), water supply (18.8\%), and Good roads and Education facilities (18.8\%). Host communities should be involved in the management of YGR, and management should ensure a more equitable and sustainable provision of basic infrastructural facilities and social amenities to the host communities. This will engender a more sustainable management and conservation of YGR.
\end{abstract}

Keywords: Benefits, host communities, infrastructural facilities, non-timber forest products, social amenities, Yankari game reserve.

\section{Introduction}

Yankari Game Reserve (YGR) is a protected area. Protected areas (PAs) are recognized as critical instruments in achieving in-situ conservation of nature, maintaining ecosystem resilience and provision of ecosystem services; water supply, food production, public health and reduction of the impacts of natural disasters among others. YGR, which is one of the oldest PAs in Nigeria, was first designated as a game reserve by the British colonialists in 1956 [1]. The establishment of this reserve marked the beginning of organized approach at Wildlife conservation in Nigeria [1, 2]. Following the adoption of National Resource Conservation Strategy in 1985 and the subsequent promulgation of Decree No.36 of 1991, YGR was upgraded to a National Park [4]. This was reverted to its initial status of a Game Reserve and handed over to the Bauchi State Government in 2006 [1].

The World conservation union (IUCN) defined PA as 'an area of land or sea especially dedicated to the protection and maintenance of biological diversity, and of natural and associated cultural resources, and managed through legal or other effective measures' [5]. Thus, conventionally, protected areas are set aside from human exploitation. When this happens, host communities are substantially denied of the numerous benefits they hitherto derive from the resources being protected. However, research has shown that with good governance, PAs can still play significant roles in sustaining their host communities [6, 7].

Various projects linking conservation and development have been implemented around protected areas with a trust to generating benefits for local communities hitherto deprived of such benefits by protection policies [8]. The Nigeria Park Service in 1981 initiated Support Zone Community Programme, as an interventionist's measure, to dissuade host communities from tempering with conservation efforts in protected areas [9, 10]. This was to be articulated by empowering the host communities economically and also providing them with other benefits like basic infrastructures and social amenities. These benefits are expected incentives for people to perceive resource and environmental conservation positively [11] and thus support it.

Correlation between conservation benefits and positive attitudes towards conservation has been confirmed by many studies $[12,13]$. Thus, providing infrastructures and welfare needs of host communities to PAs will boost community development and simultaneously reduce pressure on the PA. Corroborating this claim, Salafsky [14] asserts that the financial, economic and social benefits accruing to communities close to forests, reefs, and other natural habitats can stimulate such communities to actively conserve and spearhead the sustainable utilization of those habitats. The successful conservation of natural resources under the protected area management approach therefore depends largely on the extent to which the different interests of the stakeholders are harmonized 
Thus, from the foregoing discussion, enhancing the wellbeing of host communities to protected areas is sine-qua-non to the efficient management and conservation of resources in such PAs. Yes, host community members may not have economic needs to engage in poaching and other encroachments on PAs. Rather, they will be more proactive at protecting the area; knowing that they stand to derive more benefits with its presence. In view of the above, providing information on the current status of host community benefits from Yankari Game Reserve (YGR) would be very useful for managerial decisions about the reserve. It would also be useful in enlightening host communities towards supporting sustainable management of the reserve. This study is therefore set to determine the benefits of YGR to the host communities.

\subsection{Study Area}

\section{Methodology}

The study was carried out at Yankari Game Reserve (YGR), which spans along $9^{\circ} 50^{`} \mathrm{~N}$ and $10^{\circ} 30^{`} \mathrm{E}$ within the area of Bauchi State, Nigeria. It is surrounded by 15 host communities within the range of $1-5 \mathrm{~km}$ [15]. The Gaji and Yashi rivers dissect the Reserve giving succor and security to both fauna and flora within the Reserve. The Reserve also contain four natural warn springs, Wikki, Gwana, Dimiland and Mawulgo of which only Wikki is developed for tourists' recreation. Tourist attractions include the Marshall Caves, Dukkey wells, Shaushau and Ampara ancient iron smelting sites. 'Dogonruwa' rock paintings among others. The host communities are predominantly subsistent farmers and hunters with few engaged in petty trading businesses.

\subsection{Sampling Procedure}

A sampling intensity of 50\% was applied to randomly select eight host communities out of 15 around YGR for the study. In each host community, a systematic random sampling approach was used to identify 40 households from which the most senior male or female household member present was selected as respondent. Thus, a sample of 320 respondents was identified within the adjoining communities for the study.

\subsection{Data collection and Analysis}

Data were collected using 320 copies of a semi-structured questionnaire. This was administered on 320 respondents sampled from the households of the selected host communities to elicit information on their demographic attributes and benefits derived from YGR. These were analyzed using simple descriptive statistics.

\subsection{Result}

\section{Results and Discussion}

\subsubsection{Demographic Attributes of Host Community Members to YGR}

The result in TABLE 1 presents the demographic attributes of host community members to YGR. Sex distribution of the household heads was $76.3 \%$ and $23.7 \%$ males and females respectively. This means the household heads of host community members to YGR were male dominated.

Educational qualifications show that $35.6 \%$ had no formal education, $27.5 \%$ acquired Koranic Education, while $7.5 \%, 11.9 \%, 8.1 \%$ and $9.4 \%$ respectively acquired primary, secondary, Polytechnic and university education. The greater proportion; $63.1 \%$ (i.e. $35.6 \%+27.5 \%$ ) of the host community members had no western education. Generally, the host community members to YGR had low level of education. The marital status showed that $81.6 \%$ of the host community members were married while $18.4 \%$ were single. This means most of the host community members to YGR were married.

The result on household size shows that most households (33.1\%) comprise of 15 members and above. The next were households with 5-9 members (28.8\%), 0-4 members (20.0\%), while $18.1 \%$ of the households comprise $10-14$ members. By aggregate $51.2 \%$ (i.e. $33.1 \%+18.1 \%$ ) of the households in host communities to YGR comprise 10 members and above, which could be adjourned large.

Table 1: Demographic Attributes of Host Community Members to Yankari Game Reserve.

\begin{tabular}{|l|l|l|}
\hline Demographic attributes & Frequency & percentage \\
\hline Sex & & \\
\hline Male & 244 & 76.3 \\
\hline Female & 76 & 23.7 \\
\hline Total & 320 & 100.0 \\
\hline Educational qualification & & \\
\hline Non formal Education & 144 & 35.6 \\
\hline Koranic Education & 88 & 27.5 \\
\hline Primary School & 24 & 7.5 \\
\hline Secondary School & 38 & 11.9 \\
\hline NCE/Polytechnic Education & 26 & 8.1 \\
\hline University & 30 & 9.4 \\
\hline Total & 320 & 100.0 \\
\hline
\end{tabular}




\begin{tabular}{|l|l|l|}
\hline Marital Status & & \\
\hline Married & 261 & 81.6 \\
\hline Single & 59 & 18.4 \\
\hline Total & 320 & 100.0 \\
\hline House size & & \\
\hline $0-4$ & 64 & 20.0 \\
\hline $5-9$ & 92 & 28.8 \\
\hline $10-14$ & 58 & 18.1 \\
\hline 15 and above & 106 & 33.1 \\
\hline Total & 320 & 100.0 \\
\hline
\end{tabular}

\subsubsection{Infrastructural Benefits provided by YGR to Host Communities}

The result on benefits of YGR to its host communities presented in Table 2 revealed that, $71.3 \%$ of the respondents agreed that the host communities derived lots of benefit from YGR, while $28.7 \%$ of the respondents disagreed.

Responses on the kinds of benefits host communities derived from YGR include power supply (40.6\%), health facilities (21.8\%) and water supply (18.8\%) and Good roads and Education facilities (18.8\%). In general, power supply (transformers for stepping down power to the communities) was the most common benefit respondents knew of.

The following host communities were provided with transformers to improve power supply; they include Bogwas, Mainamaji, Garin, Dugudi, and Gaji. Similarly, dispensaries equipped with drugs were constructed in Gale, Mainamaji, and Gwala communities to improve primary health care for the people. Again, boreholes and concrete wells were provided in Dugudi, Bogwas, Kwala, and Mainamaji communities to boost water supply. Improved access roads and class room blocks were provided in Dugudi, Mainamaji, Garin, and Gaji to boost transportation and education.

Mainamaji had more of these infrastructural amenities, while Jada had none of these facilities. The presence of these facilities in Mainamaji may be due to its proximity to the main entrance to YGR. Generally, infrastructures and social amenities were poorly provided to the host communities.

Table 2: Infrastructural Benefits Provided by Yankari Game Reserve to Host Communities

\begin{tabular}{|l|l|l|l|}
\hline Benefits Category & Frequency & Percentages & Host communities Benefiting \\
\hline Awareness of Benefits & 228 & 71.3 & \\
\hline Yes & 92 & 28.7 & \\
\hline No & 320 & 100.0 & \\
\hline Total & & & \\
\hline Benefits Derived & 60 & 18.8 & Dugudi, Bogwas, Kwala, Mainamaji \\
\hline Water Supply & 130 & 40.6 & Bogwas, Mainamaji, Garin, Dugudi, Gaji \\
\hline Power Supply & 70 & 21.8 & Gale, Mainamaji, Gwala \\
\hline Health facilities & 60 & 18.8 & Dugudi, Mainamaji, Garin, Gaji \\
\hline Good roads/ Education facilities & 320 & 100.0 & \\
\hline Total & &
\end{tabular}

\subsubsection{Collection of Non-Timber Forest Products from YGR by the Host Communities}

The result on non-timber forest products (NTFPs) host communities collect from YGR is presented in Fig. 1. Majority of the respondents $(56.3 \%)$ collected fuel-wood from YGR. Other NTFPs collected were bushmeat $(16.9 \%)$, medicinal plants $(9.4 \%)$, mushroom (5.5\%), vegetables $(5.0 \%)$ and seed (3.8\%). Fruits (2.5\%) and snails $(0.6 \%)$ were the least NTFPs host communities collected from YGR. This means, fuel-wood and bush-meat were the key NTFPs most of the host community members collected from YGR.

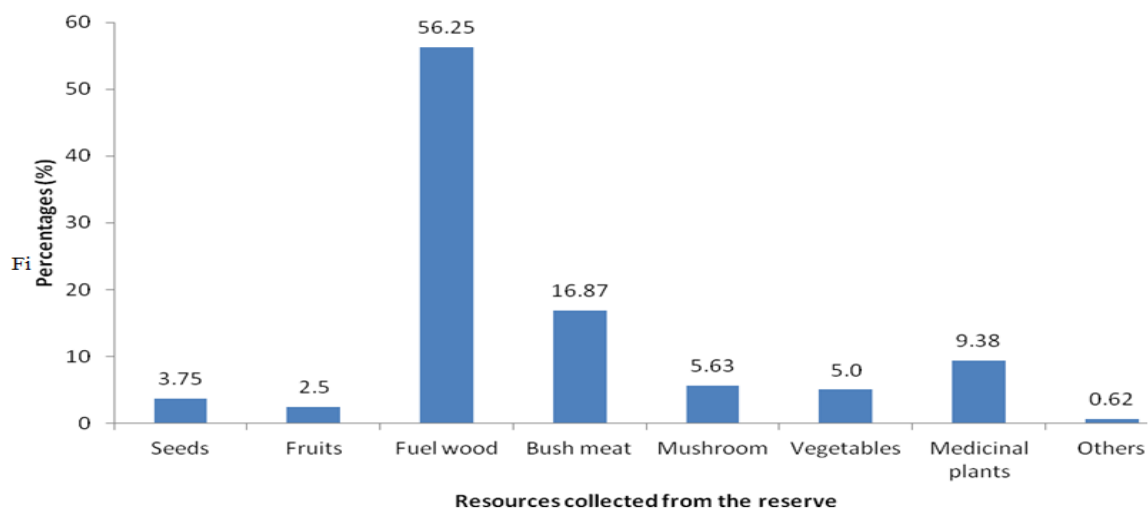

Fig 1: Resources host community members collect from Yankari game reserve 


\subsection{Discussion}

\subsubsection{Demographic attributes of Host communities to YGR}

The demographic attributes of host community members to YGR does not favor the healthy growth and development of the reserve if external and deliberate intervention is not provided. For instance, the low educational status of host community members, high proportion of married persons coupled with large household sizes portends a high dependence of host community members on the reserve for sustenance. Similarly, the dominance of male respondents as heads of households within the host communities to YGR foreshadows higher risk of encroachment on the reserve, particularly that men are said to be more destructive in harvesting products from the forest. The provision of infrastructural facilities and social amenities as well as empowering the host communities socially and economically would engender sustained management and conservation of YGR.

\subsubsection{Infrastructural Benefits provided by YGR to Host Communities}

The host communities received direct and indirect benefits from YGR. This formed part of the benefits derivable in locations with such institutions. Corroborating this claim, Lepetu and Oladele, [16] reported that natural forests under conservation in Botswana are surrounded by village communities whose livelihoods, through participatory management, are directly or indirectly bound by exploiting resources of the forests as they are economic buffers and safety nets for poor households. YGR provides bush-meat and other non-timber forest products like fruits, vegetable and firewood to adjoining communities. However, infrastructure and social amenities were ill supplied. Thus, the corporate social responsibility of the Reserve to the community was not fulfilled. Meduna [17] opined that this may cause conflict and protected area management challenges.

The harvesting of bush-meat and other NTFPs inside the reserve in order to satisfy economic and social needs of host community members portends a management threat. The locals should not be expected to still appreciate the significance of animals and other resources when their interests are not being addressed. Due to the carving out of land for the national parks and reserves, local communities lost invaluable herding resources and agricultural lands. In this instance, local people bear the cost of conservation because of foregoing the opportunity to use their land in alternate ways [18].

\section{Conclusion}

The demographic attributes of host community members to YGR does not favor the healthy growth and development of the reserve without deliberate external interventions at mitigating the effects of these attributes. Direct benefits of YGR to host community members were harvesting of NTFPs mainly fuel-wood and bushmeat. Indirect benefits like infrastructures and social amenities were poorly provided. Thus, these portend threats to effective park management and a cracked relationship between host communities and the management of YGR. Policy makers and other stakeholders in the management of YGR may use this information to plan for a more equitable and sustainable provision of basic infrastructural facilities and social amenities to the host communities to the Reserve. Furthermore, the host communities should be empowered economically and socially as this may engender a more positive relationship between park management and the host communities.

[1] Embassy Abuja. Balancing development with conservation in Yankari Game Reserve. www.cablegatesearch.net/cable Php'id = 09 ABUJA 2293. 2011

[2] Jai, J. Survival in the Sahel international service for National Agricultural Research (ISNAR), Hague, Netherlands, 200, 310pp.

[3] Anadu, P. A. Progress in the Conservation of Nigeria Wildlife. Biological Conservation, 41. 1987. 237-253.

[4] Anonymous. .Participatory Management Plan of Yankari Game Reserve, Bauchi State, Nigeria. ENVIRONCONSULT 2006. 104 pp.

[5] IUCN. The IUCN Protected Area Management Categories; 2003. Accessed 23 March, 2013. Available: http://www.iucn.org/about/union/commissions/wcpa/wcpa_work/wcpa_wpc/Index.cfm

[6] IUCN/UNEP/WWF. Managing protected areas in the tropics (IUCN, Gland, Switzerland). 1980

[7] Ghirmire, K.B., Pimbert, M.P. Social change and conservation: environmental politics and impacts of national parks and protected areas. (Earth scan, London,UK. 1997),224 pp.

[8] Wells, M., and K. E. Brandon. The principle and practice of buffer zones and local participation in biodiversity conservation. AMBIO, (22) 1993, 157-161.

[9] Tijani O.N. Evaluation of community based conservation policy in Old Oyo National Park, a doctoral thesis, Bayero University, Kano.Nigeria. 2007.

[10] Chikezie O, Maidugu Y, Joshua M, Adejoh T and Jibrin I.X. Principles and approaches of wildlife reservation, a seminar presented to land resource evaluation class. Aubakar Tafawa Balewa University, Zaria, Nigeria. 2007

[11] Bauer, H, Local Perceptions of Waza National Park, Northern Cameroon. 2003.

[12] Hamilton, A., Cunningham, A., Byarugaba, D., Kayanja, F., Conservation in a region of political instability: Bwindi Impenetrable Forest, Uganda. Conservation Biology 14, 2000, 1722-1725.

[13] Abbot, J., D. Thomas, A. Gardner, S. Neba, and M. Khen, Understanding the links between conservation and development in the Bamenda Highlands, Cameroon. World Development. 29, 2001, 1115-1136. 
[14] Salafsky, N., Cauley, H., Balachander, G., Cordes, B., Parks, J., Margoluis, C., Bhatt, S., Encarnacion, C., Russell, D., Margoluis, R., .A systematic test of enterprise strategy for community-based biodiversity conservation. Conservation Biology 15 (16), 2001 , 1585-1595.

[15] Aaron, N, Land use pressures and environmental degradation in catchment area of Yankari National Park. Yankari initiatives Trust UK. 1992, 20.

[16] Lepetu, J.P and Oladele, O.I, Socio-economic determinants of forest conservation in Botswana. Proceeding, conference on International Research on Food security, Natural Resources and Rural development. Tropentag, 2009.

[17] Meduna, A,J. Ogunjimi, A,A, And Onadeko, S.A, Biodiversity conservation problems and their implications on ecotourism in Kainji Lake National Park, Nigeria. Journal of sustainability development in Africa 10,(4), 2009.

[18] Okech, R, Wildlife-community conflicts in conservation areas in Kenya.2001. 